\title{
DEMOCRACY IN EXILE
}


A volume in the series

\section{The United States in the World}

Edited by Mark Philip Bradley, David C. Engerman,

Amy S. Greenberg, and Paul A. Kramer

A list of titles in this series is available at cornellpress.cornell.edu. 


\section{DEMOCRACY IN EXILE}

\section{Hans Speier and the Rise of the Defense Intellectual}

\section{Daniel Bessner}




\section{Copyright (C) 2018 by Cornell University}

All rights reserved. Except for brief quotations in a review, this book, or parts thereof, must not be reproduced in any form without permission in writing from the publisher. For information, address Cornell University Press, Sage House, 512 East State Street, Ithaca, New York 14850.

First published 2018 by Cornell University Press

Printed in the United States of America

Library of Congress Cataloging-in-Publication Data

Names: Bessner, Daniel, 1984- author.

Title: Democracy in exile : Hans Speier and the rise of the defense intellectual / Daniel Bessner.

Description: Ithaca : Cornell University Press, 2018. | Series: The United States in the world | Includes bibliographical references and index.

Identifiers: LCCN 2017041352 (print) | LCCN 2017043061 (ebook) | ISBN 9781501709395 (pdf) | ISBN 9781501712036 (epub/mobi) | ISBN 9780801453038 | ISBN 9780801453038 (print : alk. paper)

Subjects: LCSH: Speier, Hans. | Sociologists-United States-Biography. Sociologists-Germany-Biography. | Exiles_-GermanyBiography. | National security-United States-History20th century. | United States-Foreign relations-1945-1989. United States-Intellectual life-20th century.

Classification: LCC HM479.S (ebook) | LCC HM479.S B47 2018 (print) | DDC $301.092[\mathrm{~B}]$ - dc23

LC record available at https://lccn.loc.gov/2017041352

Cornell University Press strives to use environmentally responsible suppliers and materials to the fullest extent possible in the publishing of its books. Such materials include vegetable-based, low-VOC inks and acid-free papers that are recycled, totally chlorine-free, or partly composed of nonwood fibers. For further information, visit our website at cornellpress.cornell.edu.

Cover image: Hans Speier's Office of War Information identification badge, 1945-1946 (courtesy of the New School for Social Research). 
To my parents,

Jody and Glen Bessner 
A free-floating intelligentsia ... is not going to show us the way out of the crisis.

-Hans Speier, as recounted by Henry Kellerman, 1990

[Hans Speier was] a scholar who looked modernity in the eye and did not blink.

-Ira Katznelson, 1990 